\title{
ACEls, ARBs, ibuprofen originally linked to COVID-19: the other side of the mirror
}

\author{
Mina T. Kelleni ${ }^{1} \odot$
}

Received: 5 August 2020 / Accepted: 30 August 2020 / Published online: 12 September 2020

(c) Springer Nature Switzerland AG 2020

\begin{abstract}
During the COVID-19 pandemic, a correspondence, published at the Lancet Respiratory Medicine, that linked angiotensinconverting enzyme inhibitors, angiotensin receptor blockers and ibuprofen to a higher risk of SARS CoV-2 infection and complications, has influenced, when adopted by official health authorities, the practical management of COVID-19 with regard to non-steroidal anti-inflammatory drugs that were avoided in all COVID-19 management protocols all over the world. This manuscript discusses, from a pharmacological point of view, the points of weakness in the mentioned correspondence and it also lists some important contradictory review articles as well as clinical results that refuted its claims. The author chose to argue against each claim represented in the mentioned correspondence to confirm that ACEIs, ARBs and NSAIDs including ibuprofen should not be considered hazardous to be administered for COVID-19 patients and to warn against any future adoption of such unproved claims.
\end{abstract}

Keywords COVID-19 $\cdot$ SARS CoV-2 $\cdot$ Aceis $\cdot$ Arbs $\cdot$ Ibuprofen

$\begin{array}{ll}\text { Abbreviations } \\ \text { ACEIs } & \begin{array}{l}\text { Angiotensin-converting enzyme inhibitors } \\ \text { ARBs }\end{array} \\ \text { SARS-CoV-2 } & \begin{array}{l}\text { Angiotensin receptor blockers } \\ \text { virus } 2\end{array} \\ \text { COVID-19 } & \text { Coronavirus disease } 2019\end{array}$

\section{Introduction}

Several reports have indicated that hypertension, diabetes and coronary heart disease are more frequently encountered among COVID-19 patients and are more associated with its complications(Chen et al. 2020; Deng and Peng 2020; Zhang et al. 2020). Many researchers have tried to find a possible relationship and some have hypothesized in a correspondence that "patients treated with ACE2-increasing drugs like ACEIs and ARBs, ibuprofen and thiazolidinediones are at higher risk for severe COVID-19 infection and, therefore, should be monitored for ACE2-modulating medications"(Fang et al. 2020). This hypothesis has

Mina T. Kelleni

mina.kelleni@mu.edu.eg; drthabetpharm@yahoo.com

1 Pharmacology Department, College of Medicine, Minia University, Minya, Egypt subsequently led to a medical controversy regarding ACEIs and ARBs as well as to a recommendation against ibuprofen to be administered to COVID-19 patients as declared by France's Minister of Solidarity and Health. This recommendation was also announced by the World Health Organization before rapidly changing its stance to be neutral, declaring that it doesn't recommend against ibuprofen for COVID-19 patients (The Local 2020, March 14; WHO 2020, March 19). The main aim of this review is to examine the points of weakness of this hypothesis from a pharmacological point of view.

\section{ARE ACEls and ARBS hazardous in COVID-19?}

It has been demonstrated that SARS-CoV-2 causing COVID-19 engages the same receptor ACE2 of its predecessor SARS-CoV as the entry receptor to invade its host cells (Hoffmann et al. 2020; Zhou et al. 2020). Moreover, it was suggested that SARS-CoV-2, compared to SARS-CoV, has a more efficient binding affinity for the ACE2 receptor, which also regulates both cross-species and humanto-human transmissions, suggesting a possible mechanism for the higher contagion ability of COVID-19 (Wan et al. 2020). In their correspondence (Fang et al. 2020), our colleagues claimed that the expression of ACE2 is substantially 
increased in patients with type 1 or type 2 diabetes, who are treated with ACEIs or ARBs, thus implying a possible cause for their higher risk for complications when infected with SARS-CoV-2. Further, they also claimed that: "hypertension is also treated with ACE inhibitors and ARBs, which results in an upregulation of ACE2" citing a reference $(\mathrm{Li}$ et al. 2017) which the author suggests it has no strong relationship to their claims. On the contrary, it states that the activity and action of ACE2 are not affected by ACEIs and it also contradicts their previous suggestion stating clearly that ACE2 expression is downregulated in diabetes. Noteworthy, upon their subsequent reply to some authors who requested caution to be mandatorily practiced when recommending discontinuation or providing alternative treatment of ACEIs and ARBs (Brown); they cited other references (Fang et al. 2013) which are also strongly argued and refuted by other researchers (Devaux et al. 2020; Vaduganathan et al. 2020; Wang et al. 2020). Further, three US cardiology associations issued a joint statement to dispel the misinformation circulating about the use of ACEIs and ARB medications among patients with COVID-19, recommending their continuation to all patients(American College of Cardiology 2020, March 17). Similarly, the European Medicines Agency adopted the same conclusion, urging the patients not to interrupt their treatment with ACEIs or ARBs as well as not to switch to other medicines stating clearly that there is currently no evidence from clinical or epidemiological studies that establishes a link between ACE inhibitors or ARBs and the worsening of COVID-19 (European Medicines Agency 2020, March 27). Interestingly, in a study of 205 British inpatients with COVID-19 whom were adjusted for age, gender and comorbidities including diabetes mellitus, hypertension, ischemic heart disease and heart failure; ACEIs did not show any evidence for increasing the short-term severity of COVID-19 disease. On the contrary, they resulted in a lower rate of death or transfer to a critical care unit within seven days, suggesting a potential beneficial effects (Bean et al. 2020). Similarly, a study of thousands of COVID-19 patients showed no significant association with prior use of ACEI/ ARB with COVID-19 diagnosis or with mortality among patients (Fosbøl et al. 2020).

\section{Are NSAIDs, including ibuprofen, hazardous in COVID-19?}

Moreover, our colleagues have stated that ibuprofen and the group of antidiabetic drugs known as thiazolidinediones [which are mostly obsolete, except in developing countries (Kelleni 2018)] have similar effects on their proposed ACE2 expression, however, there were no references cited. To the best of the author's pharmacological research, there's a single published experiment that gathered those drugs and showed a protective effect of ibuprofen similar to pioglitazone, a member of the thiazolidinediones, against cardiac fibrosis in a rat model partially through their ability to increase ACE2 but in a protective manner (Qiao et al. 2015). Fang et al. might have understood these protective results found in rats for ibuprofen and thiazolidinediones to be unfortunately interpreted as a hazardous risk for COVID-19 potential patients. It is worthwhile that one of the researchers who published this hypothesis has officially announced in a statement published by his university, that their hypothesized suggestions regarding ibuprofen and the other drugs were intended for researchers not for patients and should not be considered recommendations against the usage of these drugs (University of Basel 2020, March 16). Unfortunately, this was not mentioned, at least in a clear manner, in their original correspondence; instead they suggested an alternative for ACEIs and ARBs. Interestingly, the author has published a contradictory theory suggesting ibuprofen to be not only harmful but also beneficial for COVID-19 (Kelleni 2020a, b, c, May 6). Furthermore, other researchers have also criticized the theoretical basis that led to avoidance of ibuprofen in COVID-19 and in vitro studies suggested ibuprofen may even facilitate cleavage of ACE2 from the membrane, preventing membrane-dependent viral entry into the cell (Moore et al. 2020; Smart et al. 2020). Recently, ibuprofen use in COVID-19 patients was shown not to be associated with worsening clinical outcomes, compared with paracetamol or no antipyretic (Rinott et al. 2020). Most recently, the author has provided the first clinical proof that ibuprofen, among other NSAIDs, has practically improved the immunological response as well as the time of recovery of COVID-19 patients (Kelleni 2020c, June 22).

\section{Was the original hypothesis right or not?}

ACE2 is highly expressed in the lungs and heart performing a protective physiological role and this has been shown when SARS CoV induced severe ACE2 downregulation which led to an imbalance between angiotensin 1-7 and angiotensin II levels as well as the induction of the release of many inflammatory cytokines that contributed to acute myocardial dysfunction and lung failure (Kuba et al. 2005; Oudit et al. 2009). Noteworthy, it has also been suggested that the same effect on ACE2 expression may occur with SARSCoV-2 (Hoffmann et al. 2020), and SARS CoV-2 induced ACE2 downregulation has been similarly suggested to be associated with seriously hazardous macrophage activating syndrome (Banu et al. 2020). Similarly, ACE2 is normally highly expressed in the kidneys with an overexpression that was shown early in diabetic patients producing a renal protective function, whereas ACE2 subsequent downregulation or induced loss of expression has exacerbated diabetic 
kidney injury both clinically and experimentally (Wakahara et al. 2007; Wong et al. 2007; Koitka et al. 2008).

\section{Conclusion}

Finally, the author requests health care official authorities to carefully assess their drug recommendations that might affect medical care, and to avoid recommending against any drug without proof from a well-designed clinical trial.

Acknowledgements The author would like to thank Prof. Dr. Kim D. Rainsford; Editor in Chief and Dr. Phil Berry; Deputy Editor of Inflammopharmacology for their highly valuable remarks as well as their timely and highly professional management of this manuscript. The author has tried since March 2020 to publish the main body of this manuscript and only on June 2020 a preprint has been published after a dozen of rejections without peer review (Kelleni M 2020, June 2 ,) and only Inflammopharmacology has accepted to peer review it.

Funding None.

\section{Compliance with ethical standards}

Conflict of interest None.

\section{References}

American College of Cardiology (2020) HFSA/ACC/AHA statement addresses concerns Re: using RAAS antagonists in COVID-19. from https://www.acc.org/latest-in-cardiology/artic les/2020/03/17/08/59/hfsa-acc-aha-statement-addresses-conce rns-re-using-raas-antagonists-in-covid-19. Accessed 17 Mar 2020

Banu N, Panikar SS, Leal LR, Leal AR (2020) Protective role of ACE2 and its downregulation in SARS-CoV-2 infection leading to macrophage activation syndrome: therapeutic implications. Life Sci 256:117905

Bean D, Kraljevic Z, Searle T, Bendayan R, Pickles A, Folarin A, Roguski L, Noor K, Shek A, Gallagher K, Zakeri R, Shah A, Teo J, Dobson RJB (2020) Treatment with ACE-inhibitors is associated with less severe disease with SARS-COVID-19 infection in a multi-site UK acute Hospital Trust. medRxiv: 2020.2004.2007.20056788

Brown JD (2020) Antihypertensive drugs and risk of COVID-19? The Lancet Respir Med 8(5):e28.

Chen C, Chen C, Yan JT, Zhou N, Zhao JP, Wang DW (2020) Analysis of myocardial injury in patients with COVID-19 and association between concomitant cardiovascular diseases and severity of COVID-19. Zhonghua Xin Xue Guan Bing Za Zhi 48:E008

Deng SQ, Peng HJ (2020) Characteristics of and public health responses to the coronavirus disease 2019 outbreak in China. J Clin Med 9(2)

Devaux CA, Rolain J-M, Raoult D (2020) ACE2 receptor polymorphism: susceptibility to SARS-CoV-2, hypertension, multi-organ failure, and COVID-19 disease outcome. J Microbiol Immunol Infect 53(3):425-435

European Medicines Agency (2020) EMA advises continued use of medicines for hypertension, heart or kidney disease during COVID-19 pandemic. from. https://ern-euro-nmd.eu/ema-advis es-continued-use-of-medicines-for-hypertension-heart-or-kidne y-disease-during-covid-19-pandemic/. Accessed 31 Mar 2020

Fang L, Karakiulakis G, Roth M (2013) Antihypertensive drugs and risk of COVID-19? Authors' reply. Lancet Respir Med 8(5):e32-e33

Fang L, Karakiulakis G, Roth M (2020) Are patients with hypertension and diabetes mellitus at increased risk for COVID-19 infection? Lancet Respir Med 8(4):e21

Fosbøl EL, Butt JH, Østergaard L, Andersson C, Selmer C, Kragholm K, Schou M, Phelps M, Gislason GH, Gerds TA, TorpPedersen C, Køber L (2020) Association of angiotensin-converting enzyme inhibitor or angiotensin receptor blocker use with COVID-19 diagnosis and mortality. JAMA 324(2):168-177

Hoffmann M, Kleine-Weber H, Schroeder S, Kruger N, Herrler T, Erichsen S, Schiergens TS, Herrler G, Wu NH, Nitsche,A Muller MA, Drosten C, Pohlmann S (2020) SARS-CoV-2 cell entry depends on ACE2 and TMPRSS2 and is blocked by a clinically proven protease inhibitor. Cell

Kelleni M (2018) Drug induced malignancy: a focus on pioglitazone. Pharm Pharmacol Int J 6(4):297-299

Kelleni M (2020a) Ibuprofen potential addition to COVID-19 early management protocols: could it be superior to paracetamol and hydroxychloroquine? Authorea, from https://journal.sketchings cience.org/users/318758/articles/448656-ibuprofen-potentialaddition-to-covid-19-early-management-protocols-could-it-besuperior-to-paracetamol-and-hydroxychloroquine. Accessed 6 May 2020

Kelleni M (2020b) ACEIs, ARBs, ibuprofen linked to COVID-19: the other side of the broken mirror. Authorea, from https://www. authorea.com/users/318758/articles/456017-aceis-arbs-ibupr ofen-linked-to-covid-19-the-other-side-of-the-broken-mirro $\mathrm{r}$ ?commit $=\mathrm{c} 85 \mathrm{~d} 790 \mathrm{e} 9 \mathrm{c} 1 \mathrm{c} 2 \mathrm{a} 3 \mathrm{e} 698675 \mathrm{ed} 1798 \mathrm{efe} 534 \mathrm{abdfa} 7$. Accessed 2 Jun 2020

Kelleni M (2020c) Breakthrough: Ibuprofen/nitazoxanide/azithromycin: a battle changer personalized COVID-19 telemedicine five days protocol. Authorea from https://www.authorea.com/users /318758/articles/460853-breakthrough-ibuprofen-nitazoxani de-azithromycin-a-battle-changer-personalized-covid-19-telem edicine-five-days-protocol?commit $=52337 \mathrm{e} 49 \mathrm{~b} 98 \mathrm{~b} 96 \mathrm{fae} 21 \mathrm{~d}$ ab166828780e5f544a80. Accessed 22 Jun 2020

Koitka A, Cooper ME, Thomas MC, Tikellis C (2008) Angiotensin converting enzyme 2 in the kidney. Clin Exp Pharmacol Physiol 35(4):420-425

Kuba K, Imai Y, Rao S, Gao H, Guo F, Guan B, Huan Y, Yang P, Zhang Y, Deng W, Bao L, Zhang B, Liu G, Wang Z, Chappell M, Liu Y, Zheng D, Leibbrandt A, Wada T, Slutsky AS, Liu D, Qin C, Jiang C, Penninger JM (2005) A crucial role of angiotensin converting enzyme 2 (ACE2) in SARS coronavirus-induced lung injury. Nat Med 11(8):875-879

Li XC, Zhang J, Zhuo JL (2017) The vasoprotective axes of the renin-angiotensin system: physiological relevance and therapeutic implications in cardiovascular, hypertensive and kidney diseases. Pharmacol Res 125(Pt A):21-38

Moore N, Carleton B, Blin P, Bosco-Levy P, Droz C (2020) Does ibuprofen worsen COVID-19? Drug Saf 43(7):611-614

Oudit GY, Kassiri Z, Jiang C, Liu PP, Poutanen SM, Penninger JM, Butany J (2009) SARS-coronavirus modulation of myocardial ACE2 expression and inflammation in patients with SARS. Eur J Clin Invest 39(7):618-625

Qiao W, Wang C, Chen B, Zhang F, Liu Y, Lu Q, Guo H, Yan C, Sun $\mathrm{H}, \mathrm{Hu} \mathrm{G}$, Yin X (2015) Ibuprofen attenuates cardiac fibrosis in streptozotocin-induced diabetic rats. Cardiology 131(2):97-106

Rinott E, Kozer E, Shapira Y, Bar-Haim A, Youngster I (2020) Ibuprofen use and clinical outcomes in COVID-19 patients. Clin Microbiol Infect 26(9):1259.e5-e7 
Smart L, Fawkes N, Goggin P, Pennick G, Rainsford KD, Charlesworth B, Shah N (2020) A narrative review of the potential pharmacological influence and safety of ibuprofen on coronavirus disease 19 (COVID-19), ACE2, and the immune system: a dichotomy of expectation and reality. Inflammopharmacology

The Local (2020) UPDATE - Coronavirus: French health minister and WHO issue warning over taking anti-inflammatories. From https ://www.thelocal.fr/20200314/coronavirus-french-health-ministerissues-warning-over-anti-flammatories. Accessed 14 Mar 2020

University of Basel (2020) Ibuprofen and COVID-19. From https:// www.unibas.ch/en/News-Events/News/Uni-Research/Ibuprofenand-COVID-19-Setting-the-record-straight.html. Accessed 16 Mar 2020

Vaduganathan M, Vardeny O, Michel T, McMurray JJV, Pfeffer MA, Solomon SD (2020) Renin-angiotensin-aldosterone system inhibitors in patients with COVID-19. N Engl J Med 382(17):1653-1659

Wakahara S, Konoshita T, Mizuno S, Motomura M, Aoyama C, Makino Y, Kato N, Koni I, Miyamori I (2007) Synergistic expression of angiotensin-converting enzyme (ACE) and ACE2 in human renal tissue and confounding effects of hypertension on the ACE to ACE2 ratio. Endocrinology 148(5):2453-2457

Wan Y, Shang J, Graham R, Baric RS, Li F (2020) Receptor recognition by novel coronavirus from Wuhan: An analysis based on decade-long structural studies of SARS. J Virol JVI.00127-00120
Wang JJ, Edin ML, Zeldin DC, Li C, Wang DW, Chen C (2020) Good or bad: application of RAAS inhibitors in COVID-19 patients with cardiovascular comorbidities. Pharmacol Ther 215:107628

WHO (2020) Q: could ibuprofen worsen disease for people with COVID-19? From https://twitter.com/WHO/status/1240409217 997189128. Accessed 19 Mar 2020

Wong DW, Oudit GY, Reich H, Kassiri Z, Zhou J, Liu QC, Backx PH, Penninger JM, Herzenberg AM, Scholey JW (2007) Loss of angiotensin-converting enzyme-2 (Ace2) accelerates diabetic kidney injury. Am J Pathol 171(2):438-451

Zhang JJ, Dong D, Cao YY, Yuan YD, Yang YB, Yan YQ, Akdis CA, Gao YD (2020) Clinical characteristics of 140 patients infected with SARS-CoV-2 in Wuhan, China. Allergy 75:1730-1741

Zhou P, Yang X-L, Wang X-G, Hu B, Zhang L, Zhang W, Si H-R, Zhu Y, Li B, Huang C-L, Chen H-D, Chen J, Luo Y, Guo H, Jiang R-D, Liu M-Q, Chen Y, Shen X-R, Wang X, Zheng X-S, Zhao K, Chen Q-J, Deng F, Liu L-L, Yan B, Zhan F-X, Wang Y-Y, Xiao G-F, Shi Z-L (2020) A pneumonia outbreak associated with a new coronavirus of probable bat origin. Nature 579(7798):270-273

Publisher's Note Springer Nature remains neutral with regard to jurisdictional claims in published maps and institutional affiliations. 